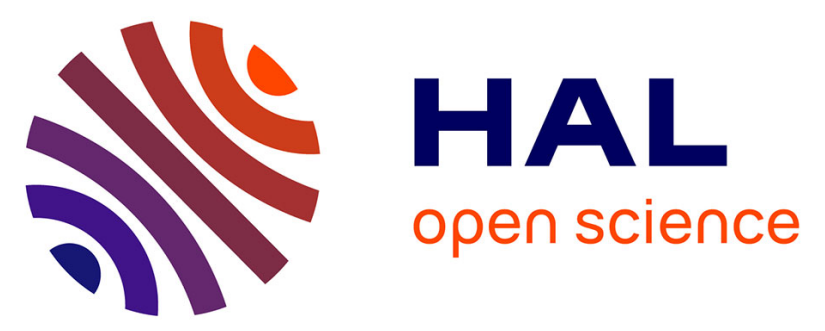

\title{
Tintinnid ciliates of the marine microzooplankton in Arctic Seas: a compilation and analysis of species records
}

\author{
John R. Dolan, Richard W. Pierce, Eun Jin Yang
}

\section{To cite this version:}

John R. Dolan, Richard W. Pierce, Eun Jin Yang. Tintinnid ciliates of the marine microzooplankton in Arctic Seas: a compilation and analysis of species records. Polar Biology, 2017, pp.1-14. 10.1007/s00300-016-2049-0 . hal-01395076

\section{HAL Id: hal-01395076 https://hal.sorbonne-universite.fr/hal-01395076}

Submitted on 14 Nov 2016

HAL is a multi-disciplinary open access archive for the deposit and dissemination of scientific research documents, whether they are published or not. The documents may come from teaching and research institutions in France or abroad, or from public or private research centers.
L'archive ouverte pluridisciplinaire HAL, est destinée au dépôt et à la diffusion de documents scientifiques de niveau recherche, publiés ou non, émanant des établissements d'enseignement et de recherche français ou étrangers, des laboratoires publics ou privés. 
Polar Biology 40: in press (2017).

\title{
Tintinnid Ciliates of the Marine Microzooplankton in Arctic Seas: a Compilation and Analysis of Species Records
}

\author{
by John R. Dolan ${ }^{1 *}$, Richard W. Pierce ${ }^{2}$, and Eun Jin Yang ${ }^{3}$ \\ 1'Sorbonne Universités, UPMC Univ Paris 06, CNRS UMR 7093, Laboratoire d'Océanographie \\ de Villefranche-sur-Mer, Station Zoologique, Villefranche-sur-Mer 06230, France \\ ${ }^{2}$ P.O. Box 132, North Attleboro MA 022761-0132, USA \\ ${ }^{3}$ Department of Polar Ocean Environment, Korea Polar Research Institute, \\ Yeonsu-gu, Incheon, South Korea \\ "correspondance
}

\section{Abstract}

We set out to examine a postulated latitudinal trend in species richness within the Arctic Ocean. We compiled species records of tintinnid ciliates in the Arctic from the literature and added our own unpublished Chukchi Sea data to produce a database (available as an Online Resource data file) consisting of 1427 records of 89 species from 414 locations above $65^{\circ} \mathrm{N}$ sampled from 1885 to 2015 . While there was no trend of species richness throughout the Arctic, there was a significant positive relationship between species richness and the number of sites sampled in a $2^{\circ}$ band, suggesting a sampling effect. Plotting cumulative numbers of species and cumulative number of sites sampled by year, we found a linear relationship in log cumulative numbers of species and log sites sampled, and a lack of a plateau in the species accumulation trend. Species records are highly dominated by 4 species, accounting for $45 \%$ of the records: Acanthostomella norvegica, Parafavella denticulata, Ptychocylis obtusa and Salpingella acuminata, all of which, except $S$. acuminata, have long been suspected to be morphologically variable, with different morphotypes given undue species status. Pooling all reported species of Acanthostomella, Parafavella and Ptychocylis yielded little qualitative differences but considerable quantitative differences. We found large discrepancies in geographic coverage. We conclude that many zones projected to experience large changes in sea ice coverage are under-sampled. Based on the historical trend, the list of Arctic tintinnid ciliate species will likely continue to grow with new sampling, regardless of changes in the Arctic Seas.

Keywords: biodiversity, biogeography, plankton, zooplankton, protist, latitudinal diversity gradient 


\section{Introduction}

Microzooplankton are a key component of planktonic food webs as they are responsible for the consumption of most of the primary production in the plankton, including in the Arctic Seas (Nelson et al. 2014). The relative importance of microzooplankton as grazers in the Arctic seas is predicted to increase due to the foreseen shifts towards smaller phytoplankters ( $\mathrm{Li}$ et al. 2009) and changes in the timing of phytoplankton blooms (Michel et al. 2012). Tintinnid ciliates are a usually minority component in the microzooplankton (McManus \& Santoferarra 2013). However, in the Arctic tintinnid ciliates can occasionally be a significant component of the grazer community (Sherr et al. 2009) and can seasonally dominate the biomass of the ciliate microzooplankton (Seuth et al. 2011). Tintinnids are also a component of the sea ice fauna (e.g., Melnokov et al. 2002). Among the microzooplankton they are unique in possessing a cylindrical or cup-shaped species-specific lorica (shell) permitting species identification with relative ease compared to most other taxa of the microzooplankton. Furthermore, an easily measured dimension of the lorica, the size of oral opening, is correlated with size of preferred prey and maximum growth rate (Montagnes 2013). Species with similar lorica oral diameters share then key ecological characteristics and can be considered as ecological redundants.

For tintinnids, global distribution patterns are, compared to most microzooplankton taxa, relatively well known. On a large scale, they display the most common global biogeographic pattern found among marine species, the bimodal diversity gradient, wherein species richness increases from high to low latitudes with a slight dip near the equator (Chaudhary et al. 2016). Recently, we examined the latitudinal pattern in morphological diversity as well as species diversity in tintinnids along a Northern Hemisphere transect from the Sea of Japan/East Sea to the High Arctic sampled in late summer of 2012, the year of record low sea ice (Dolan et al. 2016). Both species richness and morphological diversity (as numbers of distinct oral diameters) declined dramatically to low levels in the High Arctic. We found just a few species in the High Arctic of very different morphologies suggesting a marked lack of ecological redundancy in the tintinnind assemblage. However, our sampling, as with all oceanographic campaigns and indeed any sampling, yielded only snapshots of certain locales and with generally large detection limits hence, the generality of our finding for tintinnids in the Arctic Ocean overall required confirmation. Diversity gradients within the Arctic have been found previously for terrestrial plants (e.g. Jedrzejek et al. 2012) terrestrial vertebrates (Glig et al. 2012) and aquatic insects (Scott et al. 2011).

To our knowledge there have been no studies of latitudinal gradients in diversity with regard to planktonic organisms of the Arctic. Following Longhurst (1998), the Arctic Ocean 
along with its marginal seas comprises the Boreal Polar Province. The latitudinal gradients (roughly) characterising the province between $65^{\circ} \mathrm{N}$ and the High Arctic, potentially influencing species richness, include water temperature, temporal and areal extent of sea ice, water column depth as well as areal extent of the Arctic Sea (Longhurst 1998).

It has been noted that Arctic data is unusually scattered, often in obscure journals, and generally not compiled (Wassmann 2011). Previous reviews of tintinnid species distributions (i.e., Pierce \& Turner 1993; Dolan \& Pierce 2013), with regard to the Arctic, relied on the few easily available Arctic records and concerned only the genus-level. Furthermore, the analyses pre-dated several recent relatively large studies (i.e., Monti et al. 2013; Dolan et al. 2014; Feng et al. 2014; Matsuno et al. 2014; Li et al. 2016). To our knowledge, there is no inventory or checklist of tintinnid ciliates in the Arctic. It would be fair to say that tintinnid ciliates have been largely neglected. In recent large synthesis reports concerning Arctic Biodiversity (e.g., Meltotfe 2013; Jorgensen et al. 2016) and reviews of microbes in the Arctic (Dickson et al. 2016) tintinnid ciliates are not mentioned.

To address questions of the magnitude of tintinnid species and morphological diversity in the Arctic and the possible existence of geographic patterns it was necessary to construct de novo a database of species records for the Arctic. We combed the published literature for records of the presence of species in locations above $65^{\circ} \mathrm{N}$. To published records, we added our own previously unpublished data from analysis of samples obtained in 2010, 2013, 2014 and 2015 from a large suite of stations in the Chukchi Sea. The questions we sought to address were 1) What is the known taxonomic diversity of tintinnids in the Arctic Seas, 2) What is the morphological diversity, in terms of distinct sizes of oral openings, of the tintinnids found in the Arctic Seas, and 3) Is there a latitudinal diversity gradient within the Arctic Sea? While the database was assembled to answer these questions, it may also serve as baseline data, often lacking and needed to detect possible distributional shifts (Jorgensen et al. 2016), as well as providing a checklist of known Arctic morpho-species against which emerging molecular data (e.g., Lovejoy 2014; Pédros-Alio et al 2015; Stecher et al. 2016) may eventually be crossreferenced.

\section{Methods}

Google Scholar (https://scholar.google.com/) was used to identify documents containing the name of a known Arctic tintinnid genus (i.e., Acanthostomella, Leprotintinnus, Parafavella, Ptychocylis). Searches were run also for documents containing the term "arctic" as well the word "tintinnid" or "tintinnids" or "tintinnida". Articles citing documents containing a species 
record and the reference list of the articles themselves were screened by title. For some publications that reported pooled data, e.g., species found in sets of stations, the authors were contacted with a request for their data on species by sampling location (see Acknowledgements for the authors who generously supplied data). Reports from the historic literature were obtained by searching the Biodiversity Heritage Library (http://www.biodiversitylibrary.org/) for documents containing mentions of known Arctic species. It should be noted that sampling among the studies varied widely from coarse plankton nets to whole water examination. For many records tintinnid species were noted as 'by-catch' as the invesitigations were focused primarily on phytoplankton or metazoan zooplankton. Consequently no attempt was made to analyze data in terms of species per investigator publication. A species record was logged only when a binomial species name was given and a location was given, or could be determined, with a sample date (at least the year). Data were entered into a spreadsheet containing 8 columns by which records may be sorted: species, latitude, longitude, locality, reference, sample date, note (station or sample number), and system or sea (i.e., Baffin Bay, Barents Sea, Beaufort Sea, Canadian Archipelago, Chukchi Sea, Greenland Sea, Kara Sea, Laptev Sea, Norwegian Sea, White Sea). We have likely missed some of the Russian language literature not repeatedly cited. However, we have no reason to believe that such additional data would materially effect our conclusions.

We included previously unpublished data from cruises in the Chukchi Sea area in 2010, 2013,2014 , and 2015. Sampling and sampling analysis followed methods described in detail in Dolan et al. 2013, 2016. Briefly, for most stations a $20 \mu \mathrm{m}$ mesh plankton net was towed from approximately $100 \mathrm{~m}$ to the surface. Net material was fixed with either Acid Lugol's solution or Bouin's fixative and in the lab sample aliquots were examined with an inverted microscope. Our previously unpublished species records were entered under "reference" as ARA 01 Cruise for 2010, ARA 03 Cruise for 2013, ARA 05 Cruise for 2014, and ARA 06 Cruise for 2015 (see the Online Resource data file containing all species records).

To examine morphological characteristics of the Arctic species pool, each species was assigned lorica dimensions. We used the average of the range of lorica dimensions for the species given in the text descriptions by Kofoid \& Campbell 1929 as many investigators relied on the monograph for species identification. For species depicted in Kofoid \& Campbell 1929 but unaccompanied by a text description, we assigned dimensions of forms with text descriptions depicted in the plates as having very similar dimensions. For species described after 1929 the dimensions given in the original descriptions were assigned. We realise that dimensions and scales of depictions in Kofoid \& Campbell 1929 contain errors compared to the 
preferred authority of the original description or re-descriptions (e.g., Dolan 2016b; Santoferrara et al. 2016). However, the dimensions given in the text, or implied in the illustrations of Kofoid and Campbell, are likely to correspond to those of the organism observed by individual investigators compared to a more authoritative description. The final species list was crosschecked against GenBank to identify taxa for which sequence data has been deposited as of July 25th 2016.

We also distinguished some possibly doubtful species identities. Some of the tintinnid species commonly found in sub-Arctic and Arctic waters have long been suspected to form variable loricas with the morphological variants given undue status as distinct species. These suspected polymorphs are species of Acanthostomella (our own observations), Parafavella (Schulz \& Wulff 1927; Burkovsky 1973; Cardinal et al. 1997; Davis 1978) and Ptychocylis (Davis 1981).

\section{Results}

\section{Qualitative and Quantitative Characteristics of the Species Records}

We extracted data from 39 publications published between 1900 and 2015 containing records of species from locations from $65^{\circ}$ to $82^{\circ} \mathrm{N}$. Including our own new data for the Chukchi Sea, the database contains 1427 records of 89 species from 414 locations sampled from 1885 (Gran 1900) to 2015 (this report). The vast majority of records are from single time point sampling of unique localities from oceanographic cruises in summer months. Few reports gave time series data and only 2 had data from winter sampling, which interestingly yielded species similar to those found in summer sampling at the same site (Gaarder 1938; Tibbs 1967).

Table 1 summarises the contents of the database giving the list of species, the number of records by "Sea", for each species, as well as the first year the species was reported from the Arctic. Taxa for which one or more nucleotide sequences have been deposited in GenBank are shown in bold. Of the 19 tintinnid genera, 13 are represented in GenBank and of the 89 tintinnid species GenBank contains sequence data for 23 species. The complete database of species records is supplied as a Online Resource data file. Figure 1 shows the locations of all sampling points revealing large discrepancies in the geographic coverage of the data. Notably, there are no data for the Eastern Siberian Sea and there is very little data available for the Laptev Sea as well as the Canadian Archipelago.

The 4 most often reported species, in order of the number of records, were Pytchocylis obtusa, Parafavella denticulata, Acanthostomella norvegica and Salpingella acuminata, species of quite distinct morphologies (Fig. 2). The four species accounted for $45 \%$ the of species 
records (Fig. 3). These species were also the most widely distributed in terms of the number of seas from which they were reported (Table 1) and their apparent latitudinal range (Fig. 3). Remarkably, no species has been reported from all of the Arctic Seas. The number of potentially questionable records, the 'oncers' that is species recorded but once, represent 20 out of the 89 species. The suspected "polymorphs", possibly morphological variants of the most common species of Acanthostomella, Parafavella and Pytchocylis, represent 21 of the 89 species. Thus, even after subtracting potentially dubious records, the Arctic tintinnid fauna is substantial, consisting of 48 species in 16 genera. The morphological diversity, in terms of numbers of species in different size-classes of lorica oral diameter, is large as well, considering the entire species pool recorded, or the species pool remaining after removing 'oncers' and 'polymorphs' (Fig. 4). Most size-classes contained several species. Notably, the size-classes containing, or neighbouring, the 4 most commonly recorded species were the size classes containing the largest numbers of species (Fig. 4).

\section{Latitudinal and Historical Patterns}

We pooled species records in bands of $2^{\circ}$ latitude and plotted species richness against latitude. The resulting graph (Fig. 5) showed large differences in species richness among bands of latitude with perhaps a linear decline from $74^{\circ}$ to $82^{\circ}$, but no overall gradient of species diversity with latitude. The heterogeneity in species richness among bands led us to examine the relationship between the number of sites sampled within a $2^{\circ}$ band of latitude and the number of species recorded as occurring in the band. We found a significant positive relationship between species richness of a $2^{\circ}$ latitudinal band and the number of sites sampled in the band (Fig. 5). The lack of a latitudinal gradient and the apparent positive relationship of species richness with sampling effort held when excluding "polymorphs", the species recorded which are suspected of being morphological variants of another species recorded from the same latitudinal band. Examination of data concerning the Chukchi Sea, arguably the most sampled and with a large latitudinal gradient revealed the same patterns (data not shown). The Arctic Seas vary considerably in basic characteristics of latitudinal range, area, average depth, importance of freshwater input, etc. (see the online resource figure Arctic Ocean bathymetric map). However, plotting the apparent species richness of the Arctic Seas as a function of sampling effort revealed the same positive relationship (Fig. 6). The apparent strong effect of sampling effort on apparent species richness led us to examine the large-scale (over the past 120 years) historical trends. 
We found strikingly similar patterns plotting accumulated sites sampled with time from 1895 to 2015 and accumulated apparent species richness from 1985 to 2015 (Fig 6.). A simple linear correlation characterised the historical data cumulative sampling effort (log cumulutive sites) and (log) cumulative number of species recorded (inset graph in Fig. 6). The relationship resembles a typical species-area curve of a census of contiguous habitats (Preston 1962). It is important to note that temporal increases in the Arctic species inventory do not represent increases in the number of species new to science but rather new to the Arctic. There was no indication of a plateau in the relationship suggesting that further increasing sampling effort in the Arctic, that is simply by continuing to sample, will likely yield increases in the number of tintinnid species known from Arctic waters.

\section{Discussion}

\section{Qualitative and Quantitative Characteristics of the Species Records}

To put the magnitude of tintinnid species diversity in the Arctic, 89 species, in perspective, one can compare the number with total known diversity of living forms. The standard taxonomic monograph of Kofoid \& Campbell (1929) lists and illustrates about 750 species. In a more recent compendium, the list extends to over 900 species (Zhang et al. 2012). Although many catalogued "species" are likely to be synonyms (e.g. Dolan 2016b), the forms reported from the Arctic Seas appear to represent a considerable fraction of described tintinnid species not restricted to warm waters, which number about 500, based on genus characterisation (Pierce \& Turner 1993; Dolan \& Pierce 2013). A majority of the Arctic genera are represented in GenBank with at least one nucleotide sequence deposited (Table 1). Of those genera without any GenBank record, most have been recorded only a few times. However, of 2 the most abundant and long-known taxa, Acanthostomella and Parafavella, are completely absent from GenBank.

Arctic species diversity appears to be lower than that reported for the Southern Ocean, reviewed recently in Dolan et al. 2013. The records from the Southern Ocean are roughly comparable in quantity (2000 records from 402 locations) but contain 192 species. However, it is important to recall that the Southern Ocean is a much larger system as its northern border is usually taken as $40^{\circ} \mathrm{S}$. Even using a northern border of $60^{\circ} \mathrm{S}$, the surface area of the Southern Ocean is $21,000 \mathrm{~km}^{2}$ compared to the Arctic Ocean's 15,000 km² (Eakins \& Sharman 2010). Among the 89 species recorded from Artic Seas, 20 have only been found once from one locality and possibly represent stray species rather than resident forms. In comparison, among the Southern Ocean species, over a third appear to be strays, that is with only one recorded presence (Dolan et al. 2013). While many species have been found in the Arctic, the records 
mirror early reports of tintinnid assemblages being overwhelming dominated by just a few species (Gran 1900) as nearly half the records concern only 4 species (Fig. 3). In the size-class of each these frequently recorded species, are several other species of similar mouth size or lorica oral diameter (Fig. 4).

If we consider species of similar mouth size to be ecologically similar, then the pattern of several species in each size-class suggests that there is considerable ecological redundancy overall in the pool of Arctic tintinnid species based on the inventory pooling all historical records. This is in contrast to findings of little ecological redundancy from our recent study which was based on samples from a transect of stations across the western Arctic to $82^{\circ} \mathrm{N}$ (Dolan et al. 2016). The discrepancy likely reflects the fact the overall species pool described here sums a large number of samplings conducted over a long period of time. However, both the single transect data and the overall pooled data suggest that the High Arctic is apparently speciespoor. The High Arctic, characterised by a smaller areal extent and extensive sea ice coverage relative to lower lattitude Arctic Seas, may indeed be species-poor. However it is also poorly sampled and actually may harbor more species than known at present.

Interestingly, among the 4 species which dominate species records of the Arctic, 2 are also found in the Antarctic. Acanthostomella norvegica appears to be a bi-polar species found in high latitude waters of both hemispheres but absent from tropical, subtropical and temperate systems (Dolan et al. 2013). However, it is rarely abundant in Antarctic waters. The other Arctic dominant found also in Antarctic assemblages is Salpingella acuminata. It is an apparently cosmopolitan species found as a dominant form in assemblages from tropical waters (Dolan et al. 2007) to the Chuckchi Sea (Dolan et al. 2014). However, like A. norvegica it is not known to be dominant form in Antarctic waters.

\section{Latitudinal and Historical Patterns}

Our study began with a desire to confirm or refute the existence of a latitudinal diversity gradient in the Arctic Ocean. Geographic distribution of species records showed no gradient throughout the Arctic Ocean, only a decline from $74^{\circ}$ to $82^{\circ}$. While the highest latitudes do harbour a lower number of species, the highest latitudes are also the least sampled. We found a positive relationship between apparent species richness of a latitudinal zone and the number of sites sampled within the zone. This led us to examine the historical trends of species records and sampling effort. Additions to the species inventories closely corresponded with cumulative sampling effort in the crude form of the number of sites sampled. Based on our findings we predict that the species inventory will continue to grow simply as a result of increased 
cumulative sampling effort. There appears also to be a lack of baseline data on the distribution and composition of phytoplankton taxa (Daniëls et al. 2013). This considerably complicates diagnosis of the effects of changes in the Arctic for both microzooplankton and phytoplankton because baseline data is necessary to detect shifts (Jorgensen et al. 2016). In contrast, a similar situation does not appear to be the case for metazoan taxa of the zooplankton.

Zooplankton diversity has been described as well characterised except for taxa restricted to the bathypelagic layer where increased sampling is expected to reveal species new to science (Kosobokova et al 2010). Changes in circulation in the Arctic are predicted to yield major changes in the composition of metazoan zooplankton (Wassmann et al. 2015) that in contrast to phytoplankton and microzooplankton, may be detectable. In reality, the lack of long time-series data such as that available for Mediterrean zooplankton (e.g. Berline et al. 2012) prevents rigorous examination of temporal changes in the species composition at any one particular site, much less the Arctic Sea overall.

The historical species accumulation curve for tintinnid species recorded from the Arctic is difficult to assess as comparative data for other taxa is unavailable, as far we know. There are data for another locality. A recent study examined increases with time in the species inventory of tintinnid ciliates in the Bay of Villefranche in the NW Mediterranean Sea (Dolan 2016a) and data do exist for the discovery of species new to science as species described with time. Figure 8 shows data retrieved from the WoRMS database for all marine biota catalogued showing accumulated number of species with time from 1880 to 2015 along with the species accumulation curve for Arctic tintinnids from this study and the Bay of Villefranche from Dolan (2016a). Increases in inventory of described marine species worldwide with time can be attributed to sampling effort directed toward novel or previously under-sampled environments (rather than re-examining archived samples) and thus increases in cumulative sampling effort. There is a striking similarity in the slopes reflecting close correspondence in the relative rates of increases over time in the number of described species in marine biota overall and the number of tintinnid species known from sampling in the Arctic as well as a bay in the Mediterranean Sea. We suggest that this indicates that sampling effort in the Arctic has remained roughly proportional to sampling for new marine species world-wise since the beginning of the $20^{\text {th }}$ century. Unfortunately, testing such a hypothesis would be quite challenging and well beyond the scope of the present study. 


\section{Conclusion}

We found large discrepancies in geographic coverage of tintinnid species records. Many areas likely to experience large changes in sea ice coverage are under-sampled. While we found no clear trend of species richness with latitude throughout the Arctic, there was a significant positive relationship between species richness reported and the number of sites sampled in a $2^{\circ}$ band, suggesting a sampling effect. Examination of temporal trends in sampling effort and changes in the species inventory revealed a near-linear relationship in cumulative numbers of species recorded and sites sampled with time, and a lack of a plateau in the species accumulation trend. Species records are highly dominated by 4 species, accounting for $45 \%$ of the records: Acanthostomella norvegica, Parafavella denticulata, Ptychocylis obtusa and Salpingella acuminata, all of which, except $S$. acuminata, have long been suspected to be morphologically variable, with different morphotypes given undue species status. Pooling all reported species of Acanthostomella, Parafavella and Ptychocylis yielded little qualitative differences but considerable quantitative differences. The list of Arctic tintinnid ciliate species will likely continue to grow with new sampling, regardless of changes in the Arctic Seas. A perhaps more useful harbinger of change in the microzooplankton community of the Arctic would be shifts in the occurrences and ranges of the 4 historically dominant species or replacement of one the dominants by another species.

\section{Acknowledgements}

Marina Monti, Kohel Mastsuno, and Neil Swanberg supplied a substantial quantity of data. They kindly retrieved data from their own archives and sent us spreadsheets of species records from their oceanographic campaigns. We also appreciate the efforts of Kristian Seteras of the Institute of Marine Research Library in Bergen who sent us images of the many tables in Gran 1900, missing from copies available online, which provided the earliest Arctic records. We thank Sabine Agatha for providing copies of early Russian reports and Yana Eglit for helping us decipher them. Partial financial support was provided by grants from the 'K-AOOS (KOPRI, PM16040)', funded by the MOF, Korea. Comments on earlier drafts by Mark Costello, Dave Montagnes, 3 reviewers and the Editor led to significant improvements.

\section{References}

Berline L., Siokou-Frangou I, Marasovic I, Vidjak O, Fernandez de Puelles ML, Mazzocchi MG, Assimakopoulou G, Zervoudaki S, Fonda-Umani S, Conversi A, Garcia-Comas C, Ibanez F, 
Gasparini, S, Stemmann, L, Gorsky, G (2012) Intercomparison of six Mediterranean zooplankton time series. Prog Oceanogr 97-100: 76-91

Bernstein T (1931) Protist plankton of the North-West part of the Kara Sea. Trans Arctic Instit 3: 1-23 (in Russian with English summary)

Boltovskoy D, Vivequin SM, Swanberg NR (1991) Vertical distribution of tintinnids and associated microplankton in the upper layer of the Barents Sea. Sarsia 76:141-151

Boltovskoy D, Vivequin SM, Swanberg NR (1995) Tintinnids and other microplankton from the Greenland Sea: Abundance and distribution in the Marginal Ice Zone (May-June 1989). PSZNI: Mar Ecol 16:117-131

Burkovsky IV (1973) Variability of Parafavella denticulata in the White Sea. Zoologicheskiy Zhurnal, 52:1277-1285 (in Russian with English summary)

Burkovsky IV (1976) New data on tintinnids (Ciliata) of the Arctic and revision of fauna. Zoologicheskii Zhurnal 55, 325-336 (in Russian with English summary)

Burkovsky IV, Zamyshlyak YY, Poskryakova NP (1974) Revision of the fauna of Tintinnida (Ciliata) of the White Sea. Zoologicheskiy Zhurnal 53:1757-1776. (in Russian with English summary)

Bursa A (1963) Phytoplankton in coastal waters of the Arctic Ocean at Point Barrow Alaska. Arctic 16:239-262

Braarud T, Gaarder, KR, Nordli O (1985). Seasonal changes at various points off the Norwegian west coast. 1958. Fiskeridirektorates Skrifter Serie Havundersokelser 12:1-77

Cardinal A, Lafleur P-E, Bonneau E (1977) Les tintinnides (Ciliata: Tintinnida) des eaux marines et saumatres du Québec. I. Formes hyalines. Acta Protozool 16:15-22

Chaudary C, Saeedi H, Costello MJ (2016) Bimodality of latitudinal gradients in marine species richness. Trends Ecol Evol, in press

Chernova EN, Primako, EM 2011. Distribution of zooplankton in the estuary of Keretskaya Guba (White Sea). Russian J Mar Biol 37:104-110

Cleve PT (1899) Plankton collected by the Swedish expedition to Spitzbergen in 1898. Kongl Svenska Vetenskaps-Akademiens Handlingar 32, $51 \mathrm{p}$

Daniëls FJA, Gillespie LJ, Poulin M, et al. (2013) Plants. In: Meltofte H (ed.) Arctic Biodiversity Assessment. Status and trends in Arctic biodiversity. Conservation of Arctic Flora and Fauna, Akureyri, pp 311-353

Davis CC (1981) Variations of lorica shape in the genus Ptychocylis (Protozoa: Tintinnina) in relation to species identification. J Plank Res 3:433-443

Davis CC (1978) Variations of the lorica in the genus Parafavella (Protozoa: Tintinnida) in northern Norway waters. Can J Zool 56:1822-1827 
Dickson I, Walker G, Pearce DA (2016) Microbes and the Arctic Ocean. In: Hurst CJ (ed) Their World: A diversity of Microbial Environments, Advances in Environmental Microbiology I, Springer, Zurich, pp 341-381

Dolan JR (2016a) Historical trends in the species inventory of tintinnids (ciliates of the microzooplankton) in the Bay of Villefranche (NW Mediterranean Sea): Shifting Baselines. Eur. $\mathrm{J}$ Protistol, in press.

Dolan JR (2016b) Planktonic protists: little bugs pose big problems for biodiversity assessments. J Plank Res 38:1044-1051. doi: 10.1093/plankt/fbv079

Dolan JR, Pierce RW (2013) Diversity and Distributions of Tintinnid Ciliates. in Biology and Ecology of Tintinnid Ciliates: Models for Marine Plankton, Dolan JR, Agatha S, Coats DW, Montagnes, DJS, Stocker DK (eds). Wiley-Blackwell, Oxford, pp 214-243

Dolan JR, Ritchie MR, Ras J (2007) The neutral community structure of planktonic herbivores, tintinnid ciliates of the microzooplankton, across the SE Pacific Ocean. Biogeosciences 4:297310

Dolan JR, Yang EJ, Kim TW, Kang S-H (2014) Microzooplankton in a Warming Arctic: A comparison of tintinnids and radiolarians from summer 2011 and 2012 in the Chukchi Sea. Acta Protozool 52:101-113

Dolan JR, Yang EJ, Kang S-H, Rhee TS (2016) Declines in both redundant and trace species characterise the latitudinal diversity gradient in tintinnid ciliates. ISME Journal 10:2174-2183 doi:10.1038/ismej.2016.19

Eakins BW, Sharman GF(2010) Volumes of the World's Oceans from ETOPO1, NOAA National Geophysical Data Center, Boulder https://www.ngdc.noaa.gov/mgg/global/etopo1_ocean_volumes.html

Feng M, Zhang W, Xiao T (2014) Spatial and temporal distribution of tintinnid (Ciliophora: Tintinnida) communities in Kongsfjordn, Svalbard (Arctic), during summer. Polar Biol 37:291296

Gaarder KR (1938) Phytoplankton studies from the Tromso district 1930-31. Tromso Museums Arshefter. Naturhisttorisk Avd. NR. 11, 55:1-159

Glig O, Kovacs KM, Aars J et al. (2012) Climate change and the ecology and evolution of Arctic vertebrates. Ann NY Acad Sci 1249:166-190

Gran HH (1900) Hydrographic-biological studies of the North Atlantic Ocean and the coast of Nordland. Report on Norwegian Fishery and Marine Investigations 1:1- 137

Heimdal B. (1974) Composition and abundance of phytoplankton in the Ullsfjord area, North Norway. Astarte 7:17-42 
Jedrzejek B, Drees B, Daniëls FJA, Hörtzel n (2012) Vegetation discontinuities and altitudinal indicator species in mountain of West Greenland: finding the best positions and traits to observe the impact of climate warming in the Arctic. App Vegit Sci 15:432-448

Jensen F, Hansen BW (2000) Ciliates and heterotrophic dinoflagellates in the marginal ice zone of the central Barents Sea during spring. J Mar Biol Assoc U.K. 80:45-54

Jorgensen LL, Archambault P, Armstrong C, et al. (2016) Chapter 36G. Arctic Ocean In: "The Group of Experts of the Regular Process" Innisss L, Simcock (joint coordinators) The First Global Integrated Marine Assessment, United Nations, NY, 47 pp

Kofoid CA, Campbell AS 1929. A conspectus of the marine and freshwater ciliata belonging to the suborder Tintinnoinea, with despcriptions of new species principally from the Agassiz Expedition to the Eastern Tropical Pacific 1904-1905. Univ Calif Publ Zool, 34:1-403

Kosobokova KN, Hopcroft RR, Hirche H-J (2010) Patterns of zooplankton diversity through the depths of the Arctic's central basins. Mar Biodiv, doi: 10.1007/s12526-010-0057-9

Kubiszyn AM, Piwosz K, Wiktor JM jr, Wiktor JM (2014) The effect of inter-annual Atlantic water inflow variability on the planktonic protist community structure in the West Spitsbergen waters during the summer. J Plank Res 36:1190-1203

Lee, K-H, Chung K-H, Soh HY, Lee W. (2003) On the distribution of zooplankton in the southeaster Barents Sea during July 2002. Korean J Environ Biol 21:392-399

Levinsen H, Nielsen TG, Hansen, BW (1999) Plankton community structure and carbon cycling on the western coast of Greenland during the stratified summer situation. II. Heterotrophic dinoflagellates and ciliates. Aquat Microb Ecol 16:217-232

Li H, Xu Z, Zhang W, Wang S, Zhang G, Xiao T (2016) Boreal tintinnid assemblage in the Northwest Pacific and its connection with the Japan Sea in summer 2014. PLoS ONE11: e0153379. doi:10.1371/journal.pone.0153379

Li, W.K.W., McLaughlin, F.A., Lovejoy, C., Carmack, E.C. 2009. Smallest algae thrive as the Arctic Ocean freshens. Science 326:539

Longhurst A (1998) Ecological geography of the sea. Academic Press, San Diego, pp 101-108

Lovejoy C (2014) Changing views of Arctic protists (marine microbial eukaryotes) in a changing Arctic. Acta Protozool 53:91-100

Lovejoy C, Legendre L, Martineau M-J, Bacle J, von Quillfeldt CH (2002) Distribution of phytoplankton and other protists in the North Water. Deep-Sea Res II 49:5027-5047

Lutter S, Taasen J., Hopkins CCE, Smetacek V (1998) Phytoplankton dynamics and sedimentation processes during spring and summer in Balsfjord, Northern Norway. Polar Biol 10: $113-124$ 
Montagnes DJS (2013) Ecophysiology and behavior of tintinnids. In: Dolan JR, Montagnes DJS, Agatha S, Stoecker DK (eds) The Biology and Ecology of Tintinnid Ciliates: Models for Marine Plankton. Wiley-Blackwell, Oxford, U.K. pp 85-121

Matsuno K, Ichinomiya M, Yamaguchi A, Imai I, Kikuchi T (2014) Horizontal distribution of microprotist community structure in the western Arctic Ocean during late summer and early fall of 2010. Polar Biol, 37:1185-1195

McLaughlin F, Carmack E, O'Brien M et al. (2009) Physical and chemical data from the Beaufort Sea and Western Canadian Arctic Archipelago, September 2 to 16 2000. Canadian Data Report of Hydrography and Ocean Science 180, 167 pp

McManus GB, Santoferrara LF (2013) Tintinnids in microzooplankton communities. In: Dolan JR, Montagnes DJS, Agatha S, Stoecker DK (eds) The Biology and Ecology of Tintinnid Ciliates: Models for Marine Plankton. Wiley-Blackwell, Oxford, U.K. pp 198-213

Meschkat, A. 1939. Untersuchung über das Herbstplankton im Bereich des "Ostilandstromes". Intern Revue Hydrobiol Hydrogr 38:285-352

Melnikov, I.A., Kolosova, E.G., Welch, H.E., Zhitina, L.S. 2002. Sea biological communities and nutrient dynamics in the Canada Basin of the Arctic Ocean. Deep-Sea Res. I 49:1623-1649

Michel C, Bluhm B. Gallucci V et al., 2012. Biodiversity of Arctic marine ecosystems and responses to climate change. Biodiversity 13: 200-214

Monti M, Minocci M (2013) Microzooplankton along a transect from northern continental Norway to Svalbard. Polar Res 32:19306, doi:10.3402/polar.v32i0.19306

Nelson RJ, Ashjian CJ, Bluhm, B Conlan KE et al. (2014) Biodiversity and biogeography of the lower trophic taxa of the Pacific Arctic Region: Sensitivities to climate change. In: Grebbmeier JM, Maslowski W (eds) The Pacific Arctic Region: Ecosystem Status and Trends in a Rapidly Changing Environment, Springer, Dordrecht, pp 269-336

Ostenfeld H (1910) Marine plankton from the East-Greenland Sea (W. of $6^{\circ}$ W. Long. and N. of $73^{\circ} 30$ 'Lat.) collected during the Danmark Expedition" 1906-1908. II. Protozoa. DanmarmEkspeditionen til Gronlands Nordostkyst 1906-1908 under ledelse af I. Mylius-Erichsen. 3: 288299

Ostenfeld CH Paulsen O (1911) Marine plankton from the East-Greenland Sea (W. of $6^{\circ} \mathrm{W}$. Long. and N. of $73^{\circ} 30^{\prime}$ Lat.) collected during the Danmark Expedition" 1906-1908. IV. General remarks on the microplankton. Danmark-Ekspeditionen til Gronlands Nordostkyst 1906-1908 under ledelse af I. Mylius-Erichsen. 3: 319-336

Paranjape MA (1987) The seasonal cycles and vertical distribution of tintinnines in Bedford Basin, Nova Scotia, Canada. Can J Zool 65:41-48

Pedros-Alio C, Potvin M, Lovejoy C (2015) Diversity of planktonic microorganisms in the Arctic Ocean. Prog Oceanogr 139:233-243 
Pierce RW, Turner JT (1993) Global biogeography of marine tintinnids. Mar Ecol Prog Ser 94:11-26

Piontek J, Sperling M, Nöthig E-M, Engel A (2014) Regulation of bacterioplankton activity in Fram Strait (Arctic Ocean) during early summer: the role of organic matter supply and temperature. J Mar Syst 132:83-94

Preston FW (1962) The canonical distribution of commoness and rarity: Part 1. Ecology, 43:185-215

Ratkova TN, Wassmann P, Verity PG, Andreassen IJ (1998) Abundance and biomass of pico-, nano-, and microplankton on a transect across Nordvestbanken, north Norwegian shelf in 1994. Sarsia 84:213-225

Rossolimo LL (1927) Planktonic ciliates of the Kara Sea. Tr. Plavuch. morsk. n.-i. in-ta, 2, 2:6377 (in Russian with German summary)

Santoferrara LF, Bachy C, Alder VA et al. (2016) Updating biodiversity studies in loricate protists: the case of the tintinnids (Alveolata, Ciliophora, Spirotrichea). J Eukaryot Microbiol, doi: 10.1111/jeu.12303

Schulz B, Wulff A (1927) Hydrographische und planktologische Ergebnisse der Fahrt des Fischereischutzbootes "Zeiten" in das Barentsmeer im August-September 1926. Ber Dtsch Wiss Komm Meeresforsch 3:211-280

Scott RW, Barton DR, Evans MS, Keating JJ (2011) Latitudinal gradients and local control of aquatic insect richness in a large river system in northern Canada. J N Am Benthol Soc 30:621634

Seuthe, L., Iversen, K.R., Narcy, F. 2011. Microbial processes in a high-latitude fjord (Kongsfjorden, Svalbard): II. Ciliates and dinoflagellates. Polar Biol 34:751-766

Sherr, E.B., Sherr, B.F., Hartz, A.J. 2009. Microzooplankton grazing impact in the Western Arctic Ocean. Deep-Sea Res II 56:1264-1273

Smayda, TJ (1958) Phytoplankton studies around Jan Mayen Island. March - April,1955. Nytt Magasin for Botanikk 6, 75-96

Stecher, A., Neuhaus, S., Lange, B., Frickenhaus, S., Beszteri, A., Kroth, P.G., Valentin, K. 2016. rRNA andrDNA based assessment of sea ice protist biodiversity from the central Arctic Ocean. Eur. J. Phycol.51:31-46

Tibbs JF (1967) On some planktonic protozoa taken from the track of drift station ARLISI, 196061. Arctic 20: 247-254

Wassmann, P. 2011. Arctic marine ecosystems in an era of rapid climate change. Prog. Oceanogr. 9:0:1-17

Wassmann P, Kosobokova KN, Slagstad D, et al. (2015) The contiguous domains of Arctic Ocean advection: Trails of life and death. Prog Oceanogr 139:42-65 
WoRMS Editorial Board (2016). World Register of Marine Species. Available from http://www.marinespecies.org at VLIZ. Accessed 2016-07-14. doi:10.14284/170

Yang EJ, Choi JK, Kim SY, Chung KH, Shin H-C, Kim Y (2004) Spatial distribution and community structure of heterotrophic protists in the Central Barents Sea of Arctic Ocean during Summer. Ocean Polar Res 26: 567-579

Yokoi N, Matsuno K, Ichinomiya M, et al. (2016) Short-term changes in a microplankton community in the Chukchi Sea during autumn: consequences of a strong wind event. Biogeosciences 13:913-923.doi:10.5194/bg-13-913-2016

Zhang W, Feng M, Yu Y, Zhang C, Xiao T. (2012) An Illustrated Guide to Contemporary Tintinnids in the World. Science Press, Beijing. 499 pp 
Table 1. List of species recorded from Arctic Seas. Number of records for the Greenland Sea (GS), Baffin Bay (BB), Canadian Archipelago (CA), Beaufort Sea (Be S) Chukchi Sea (CS), Laptev Sea (LS), Kara Sea (KS), Barents Sea (BS), White Sea (WS) and Norwegian Sea (NS). References given in Table 2. Taxa in bold denote sequence data present in GenBank as of July 25 2016.

\section{Species}

Acanthostomella conicoides

Acanthostomella gracilis

Acanthostomella norvegica

Bursaopsis vitrea

Canthariella pyramidata

Codonellopsis frigida

Codonellopsis lagunela

Codonellopsis morchella

Codonellopsis ovata

Codonellopsis pusilla

Codonellopsis schabi

Eutintinnus apertus

Eutintinnus tenuis

\section{Favella azorica}

Helicostomella fusiformis

Helicostomella subulata

Leprotintinnus bottnicus

Leprotintinnus pellucidus

Metacylis vitreoides

Ormosella trachelium

Parafavella acuta

Parafavella cylindrica

Parafavella denticulata

Parafavella dilatata

Parafavella edentata

Parafavella elegans

Parafavella faceta

Parafavella gigantea

Parafavella hemifusus

Parafavella jorgensi

Parafavella media

Parafavella obtusa

Parafavella obtusangula

Parafavella parumdentata

Parafavella promissa

Parafavella robusta

Parafavella rotundata

Parafavella subrotundata

Parafavella tenuis

Parafavella ventricosa

Ptychocylis acuta

Ptychocylis arctica

Ptychocylis cylindrica

Ptychocylis drygalski

Ptychocylis minor

Ptychocylis obtusa

Ptychocylis urnula

Salpingacantha perca

Salpingacantha simplex

Salpingella acuminata

Salpingella curta

Salpingella faure

Salpingella secata

Salpingacantha ungiculata

Schmidingerella serrata

Schmidingerella

taraikaensis

Steenstrupiella robusta

\begin{tabular}{|c|c|c|c|c|c|c|c|c|c|c|}
\hline \multirow[t]{3}{*}{$\begin{array}{l}\mathbf{G} \\
\mathbf{S}\end{array}$} & BB & CA & Be S & cs & LS & KS & Ba S & WS & NS & references \\
\hline & & & & 5 & & & & & & 27,35 \\
\hline & 1 & 3 & & & & & & & & $\begin{array}{l}20,34 \\
1,2,3,4,5,11,12,13,15,16,17,18,19,23,24,26,27,28,29,35,36,37,3\end{array}$ \\
\hline \multirow[t]{10}{*}{35} & 2 & & & 63 & & 12 & 16 & & 25 & 8,39 \\
\hline & & & & 1 & & & & & & 10 \\
\hline & & & & 2 & & & & & & 35 \\
\hline & & & & 10 & & & & & & $14,22,35$ \\
\hline & & & & & & & & & 2 & 28,30 \\
\hline & & & & 1 & & & & & & 35 \\
\hline & & & & & & & & 1 & & 3 \\
\hline & & & & & & & & 1 & & 3 \\
\hline & & & & 1 & & & & & & 35 \\
\hline & & & & 1 & & & & & & 9 \\
\hline \multirow[t]{5}{*}{2} & & & & & & & & & & 13 \\
\hline & & & & 10 & & & & & & 35 \\
\hline & & & & & & & & & 1 & 12 \\
\hline & & & & 2 & & & & 2 & 6 & $12,22,3,24,30,14$ \\
\hline & & & & & 1 & 1 & & 1 & & 3,33 \\
\hline 2 & 4 & & 6 & 24 & & 12 & 14 & & 8 & $1,2,3,4,9,11,12,14,17,19,22,30,32,36,39$ \\
\hline \multirow[t]{4}{*}{1} & & & & 3 & & 3 & & & & $1,3,22,32$ \\
\hline & & & & 1 & & & & & & 35 \\
\hline & & & & & & 7 & & & & 1,3 \\
\hline & & & & & & & 17 & & 1 & $\begin{array}{l}1,8,36 \\
1,2,3,24,8,30,29,12,13,15,23,16,17,18,19,27,25.32,33,34,36,37\end{array}$ \\
\hline \multirow[t]{2}{*}{76} & 9 & 1 & & 1 & 1 & 9 & 10 & 2 & 20 & 38 \\
\hline & & & & & & & & & 1 & 8 \\
\hline 3 & & & & & & & & & 2 & $5,11,12,30$ \\
\hline \multirow[t]{2}{*}{1} & 1 & 9 & 2 & 2 & & & & & 1 & $7,14,15,26,34$ \\
\hline & & & & 3 & & & & & & 14 \\
\hline \multirow[t]{3}{*}{24} & 2 & & 8 & 1 & & 18 & 5 & 13 & & $22,6,8,11,29,26,15,16,17,18,31,21$ \\
\hline & & & & & & & 3 & & & 1 \\
\hline & & & & 15 & & & & & & 14.35 \\
\hline \multirow[t]{2}{*}{3} & & & & & & & & & & 5 \\
\hline & & & & & & & & 1 & & 3 \\
\hline \multirow[t]{3}{*}{1} & & & & & & & & & 1 & 8,26 \\
\hline & & & & 9 & & 2 & & 9 & 1 & $8,10,22,39$ \\
\hline & & & & 1 & & & & & & 14 \\
\hline \multirow[t]{5}{*}{14} & & & & & & 9 & & & 1 & $1,9,18$ \\
\hline & & & & & & 6 & & & 1 & 1,30 \\
\hline & & & & 1 & & 10 & & & & $1,6,22$ \\
\hline & & & & & & 2 & & & & 1 \\
\hline & & & & 2 & & & & & & 14 \\
\hline \multirow[t]{3}{*}{1} & 1 & & & & & & 3 & & 1 & $7,29,26,15$ \\
\hline & & & & 1 & & & & 1 & 4 & $3,4,7,12,30$ \\
\hline & & & & & & & & & 3 & 12,30 \\
\hline \multirow[t]{2}{*}{9} & & & 10 & & & & & & & 16,21 \\
\hline & & & & & & & & & 1 & $\begin{array}{l}7 \\
22,9,10,1,2,3,4,5,7,11,12,30,29,13,14,15,16,17,18,25.32,35,36,3\end{array}$ \\
\hline 71 & 5 & 9 & 1 & 116 & & 20 & 9 & 13 & 13 & $\begin{array}{l}9 \\
4,12,16,30,36,38\end{array}$ \\
\hline \multirow[t]{3}{*}{31} & & & & 1 & & 7 & & & 8 & \\
\hline & & & & 1 & & & & & & 35 \\
\hline & & & & 14 & & & & & & 22 \\
\hline \multirow[t]{8}{*}{18} & & & 23 & 66 & & 2 & 2 & 1 & 11 & $2,3,4,9,10,12,16,21,22,28,30,36,37,38$ \\
\hline & & & & & & & & & 2 & 17 \\
\hline & & & & 65 & & & & & & $9,10,22$ \\
\hline & & & & & & 3 & 3 & & & 29 \\
\hline & & & & & & & 1 & & & $\begin{array}{l}29 \\
12,30,38\end{array}$ \\
\hline & & & & & & & & & 5 & \\
\hline & & & & & & & & 1 & & 3 \\
\hline & & & & & & & & 1 & & 3 \\
\hline
\end{tabular}

First

2010

1988

1899

2012

2010

2010

1945

2010

1970

1970

2010

2011

1994

2010

1930

1898

1927

1907

1907

2010

1925

1921

1895

1975

1898

1975

2014

1907

1925

2010

1898

1970

1975

1975

2014

1906

1925

1921

1925

2014

1975

1926

1930

1935

1975

1898

1921

2010

2010

1921

2008

2010

1925

1993

1930

1970

1970 


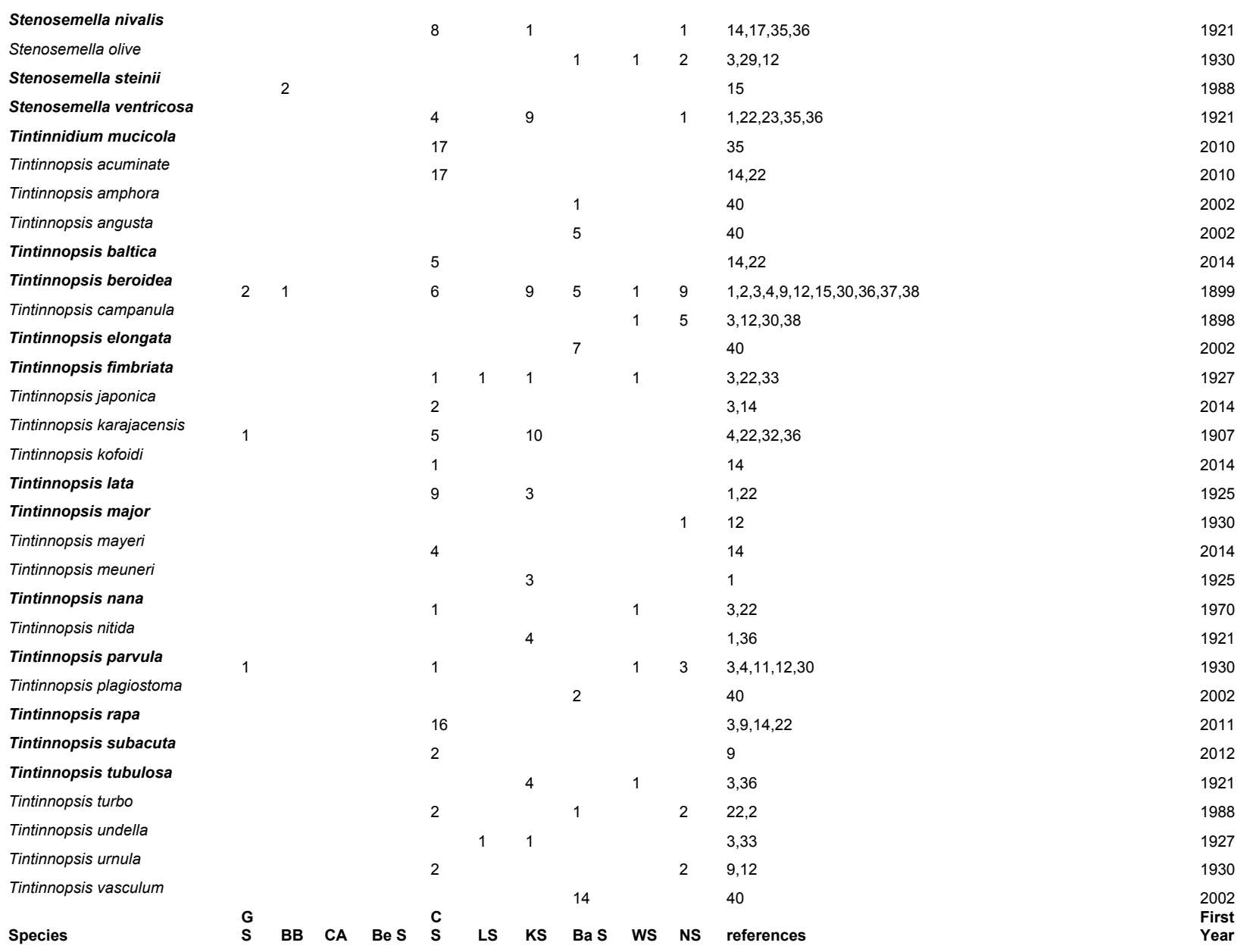


Table 2. Sources of Arctic records of tintinnids, References numbers as noted in Table 1.

\begin{tabular}{|c|c|}
\hline Reference \# & Citation (for full reference see "References") \\
\hline 1 & Bernstein 1931 \\
\hline 2 & Boltovskoy et al. 1991 \\
\hline 3 & Burkovskii 1976 \\
\hline 4 & Bursa 1963 \\
\hline 5 & Cleve 1899 \\
\hline 7 & Davis 1981 \\
\hline 8 & Davis 1978 \\
\hline 9 & Dolan et al. 2014 \\
\hline 10 & Dolan et al. 2016 \\
\hline 11 & Feng 2014 \\
\hline 12 & Gaarder 1938 \\
\hline 13 & Levinsen et al. 1999 \\
\hline 14 & Li et al. 2016 \\
\hline 15 & Lovejoy et al. 2002 \\
\hline 16 & Meschkat 1939 \\
\hline 17 & Monti et al. 2013 \\
\hline 18 & Ostenfeld \& Paulsen 1911 \\
\hline 19 & Paranjape 1987 \\
\hline 20 & Smayda, 1958 \\
\hline 21 & Tibbs 1967 \\
\hline 22 & Present Study: Chukchi Sea data 2010, 2013, 2014, 2015 \\
\hline 23 & Lutter et al 1989 \\
\hline 24 & Chernova \& Primakov 2011 \\
\hline 25 & Yokoi et al 2016 \\
\hline 26 & Kubiszyn et al 2014 \\
\hline 27 & Piontek et al 2014 \\
\hline 28 & Braarud et al 1958 \\
\hline 29 & Jensen \& Hansen 2000 \\
\hline 30 & Heimdal 1974 \\
\hline 31 & Ratkova et al. 1994 \\
\hline 32 & Ostenfeld 1910 \\
\hline 33 & Burkovskii et al. 1974. \\
\hline 34 & McLaughlin et al 2009 \\
\hline 35 & Matsuno et al 2014 \\
\hline 36 & Rossolimo 1927 \\
\hline 37 & Boltovskoy et al 1995 \\
\hline 38 & Gran 1900 \\
\hline 39 & Yang et al. 2004 \\
\hline 40 & Lee et al. 2003 \\
\hline
\end{tabular}


Figure 1. Map of the locations sampled from 1885 to 2015 from which one or more tintinnid species was reported. Note that there does not appear to any historical bias with regard to a dominance of nearshore compared to open water sampling.

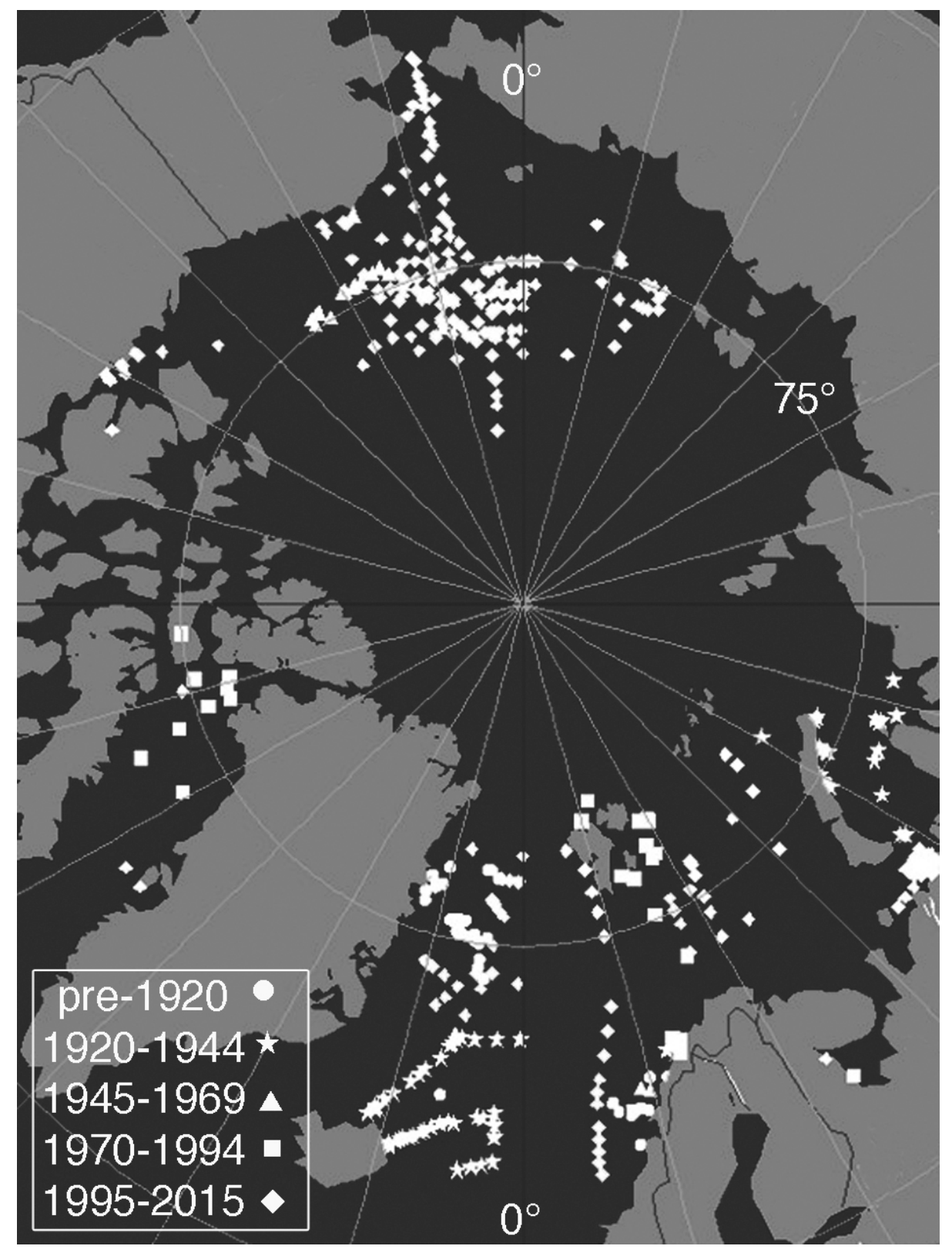


Figure 2. Micrographs of the 4 most commonly reported tintinnids from Arctic waters: A. Salpingella acuminata, B. Acanthstomella norvegica, C., Ptychocylis obtusa, and. D. Parafavella denticulata. All Lugol's-fixed specimens except for D, a Bouin's-fixed cell.

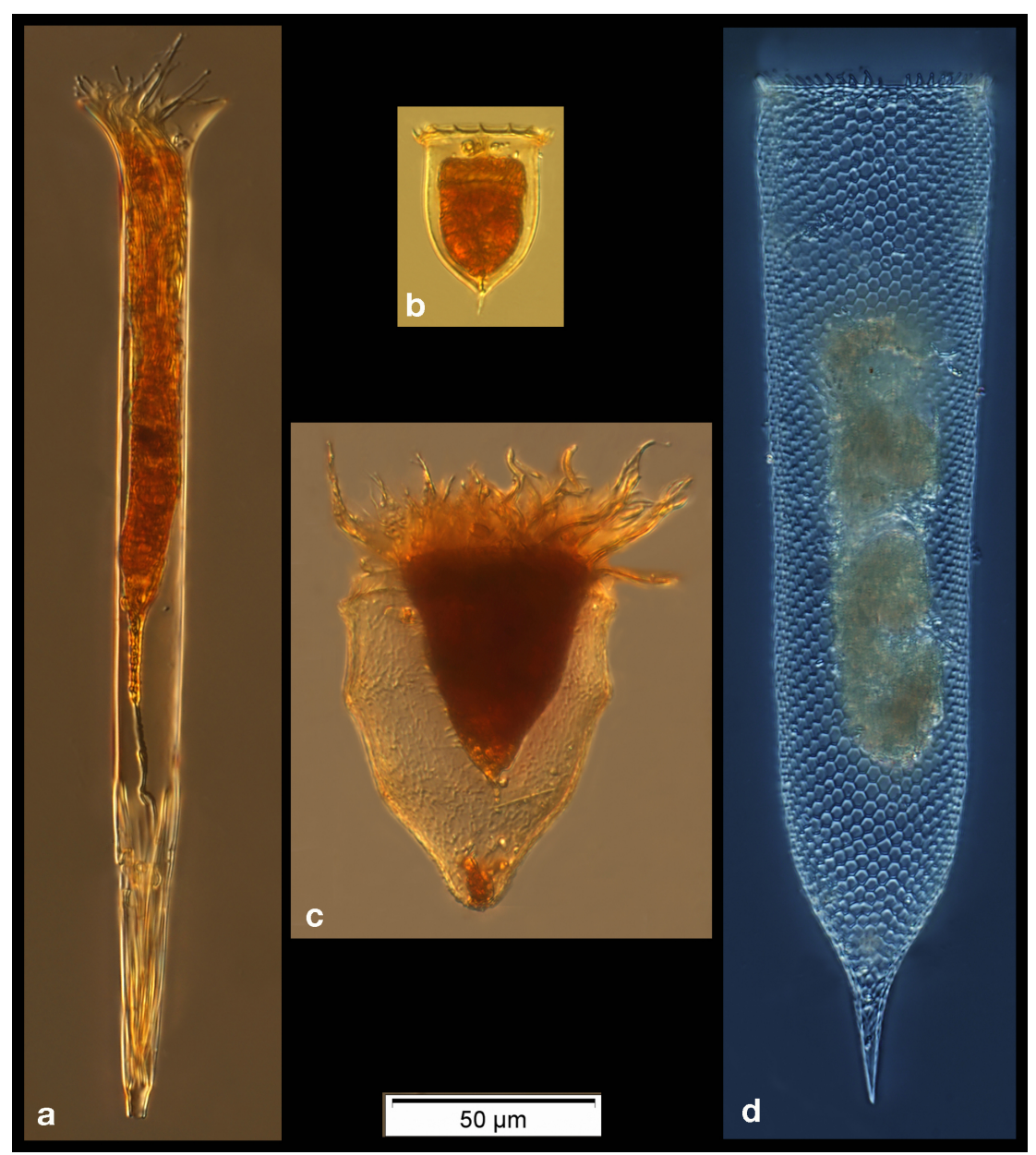


Figure 3. Plot of occurrence rank (left panel) and apparent latitudinal range vs. the number of records for the species (right panel). Remarkably, 4 species account for a large fraction of the species records and these most frequently recorded forms are also those with the largest apparent latitudinal range (species with but a single record were excluded). Note that while a species recorded but once will by definition have no latitudinal range, species with multiple records may or may be recorded across a range of latitudes.

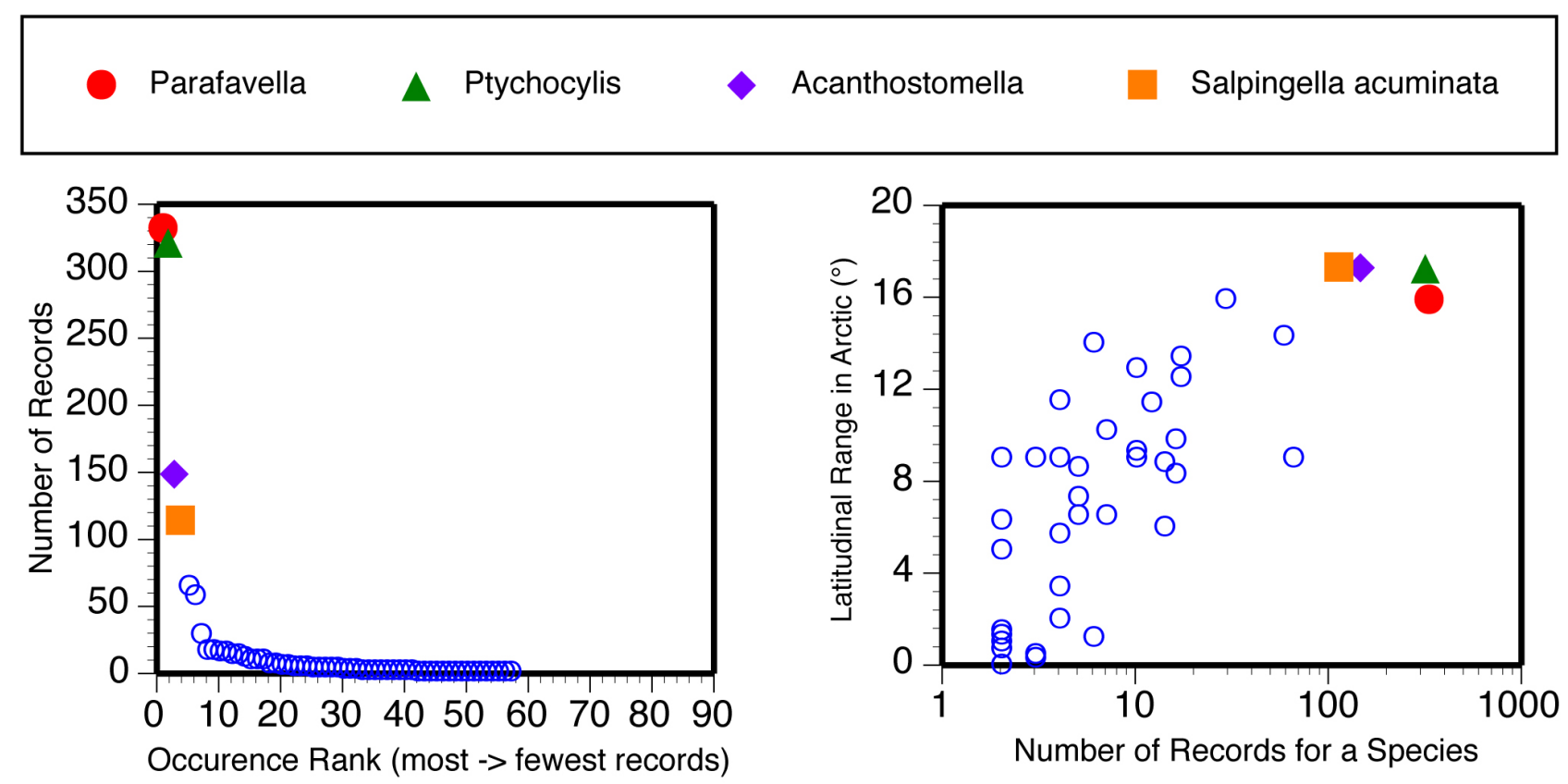


Figure 4. Morphological characteristics of tintinnid species found in the Arctic, frequency distribution of lorica oral diameters, or mouth sizes. Species were binned in size classes of 4 $\mu \mathrm{m}$. Data shown for all reported species (all Arctic Species) and the reduced pool of species remaining after removing species recorded only once and suspected morphological variants of a main species (Arctic Species w/o Oncers \& Polymorphs). The size classes containing the most frequently recorded species are shown with an asterix. Note that $x$-axis breaks used to include the large size classes omitting empty intermediate size-categories.

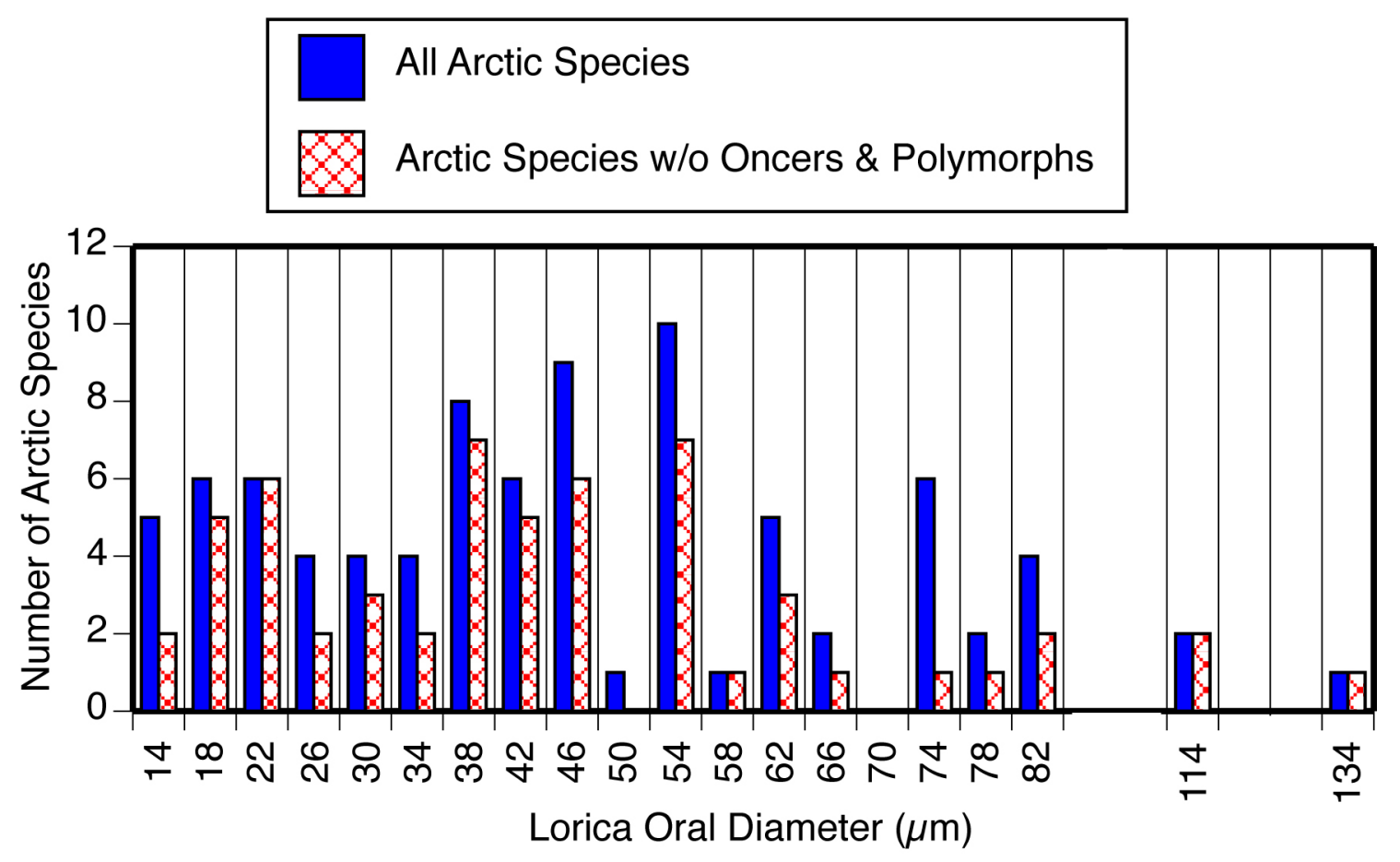


Figure 5. Species richness as a function of latitude, pooling data in bands of $2^{\circ}$ latitude (left panel) and species richness as a function of the number of sites sampled within the $2^{\circ}$ band of latitude (right panel). For both plots total numbers of species as recorded in publications are shown as well numbers of species without suspected polymorphs, morphological variants of the other species also recorded in the band of latitude. Note the lack of consistent latitudinal gradient in species richness throughout the Arctic and the correlation of species richness within a band of latitude with the number of sites sampled within the band. For total species (\# spp) $r=$ 0.70 ; for species excluding records of suspected morphological variants (w/o polymorphs) $r=$ 0.63 .

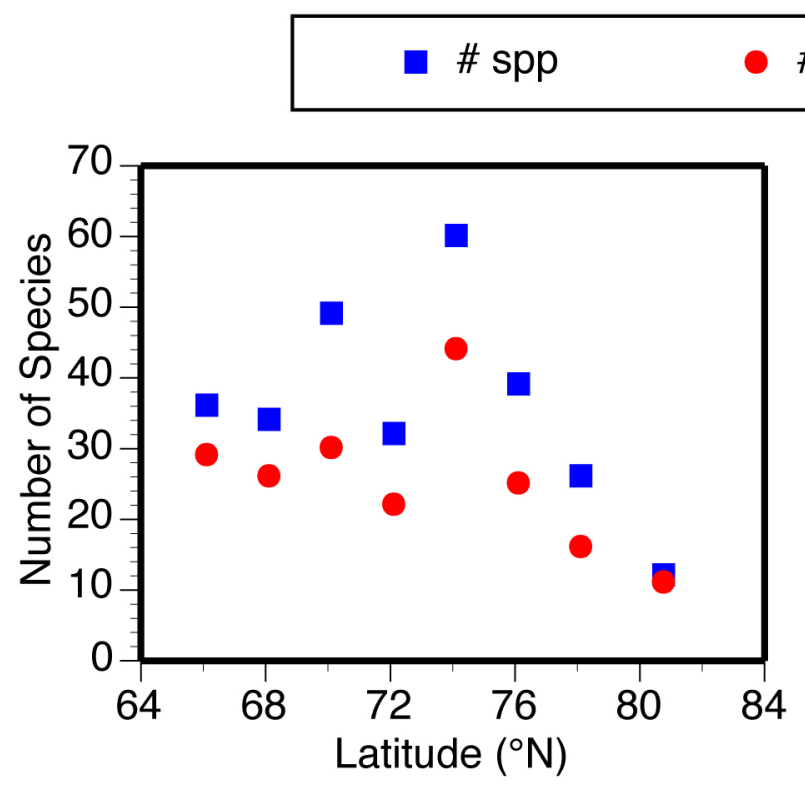

\# spp w/o polymorphs

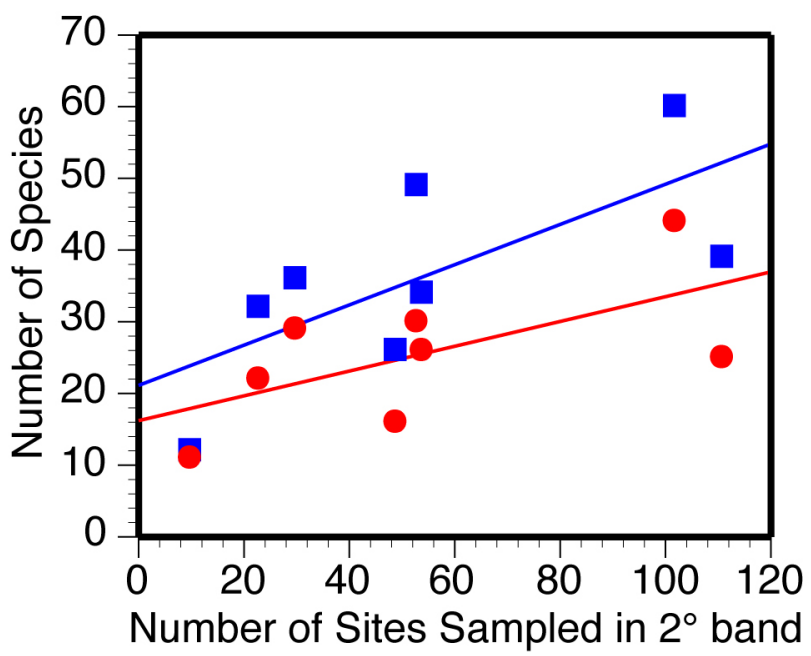


Figure 6. Species richness of the Arctic Seas as a function of the number sites sampled within the Sea. The Seas differ considerably in basic characteristics of area, latitudinal range, average depth, freshwater input, ice cover, etc., (see Online Fig. 1). Note the positive relationship of species richness with sampling effort, $n=10, r^{2}=0.66, p<0.05$.

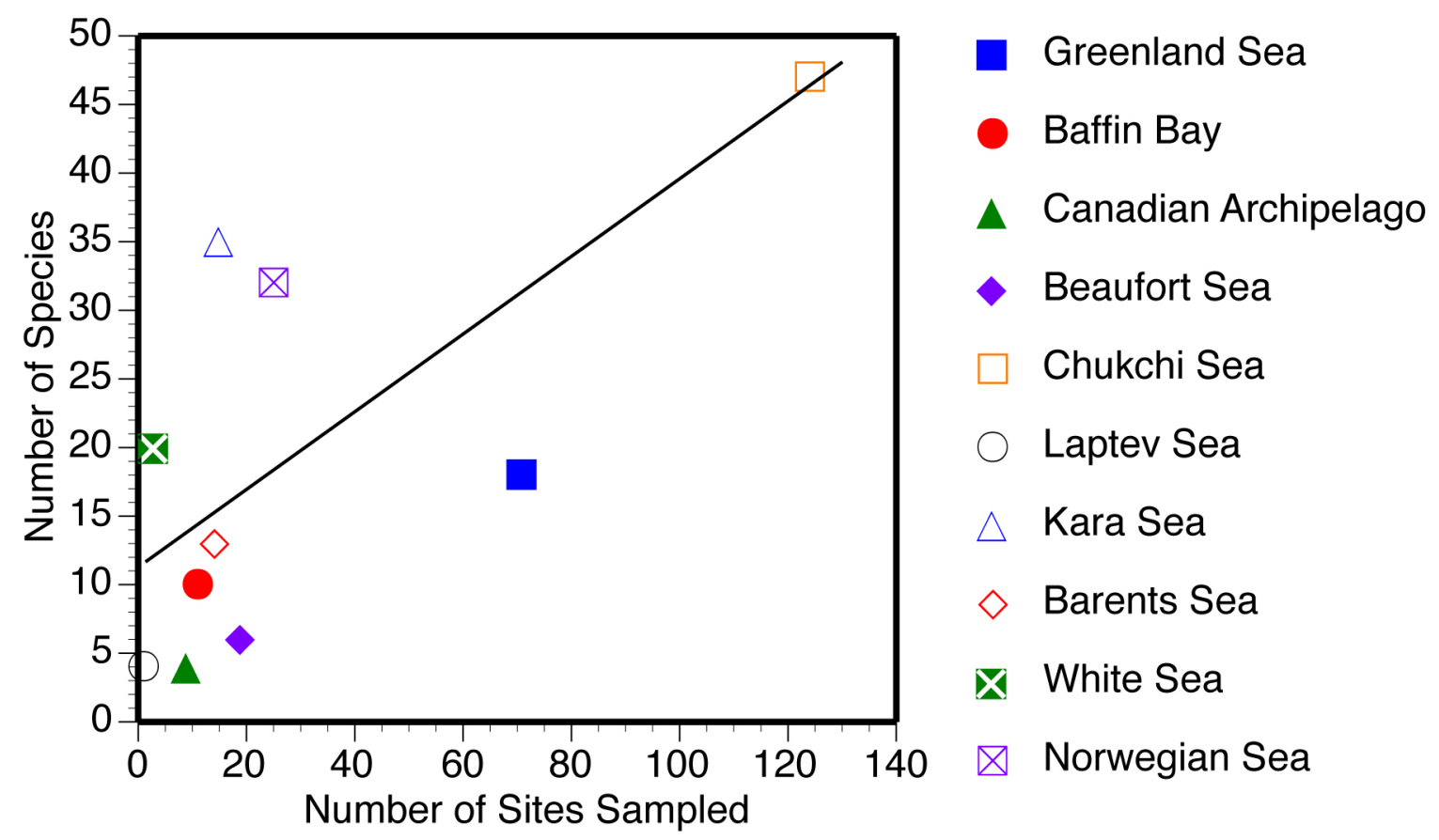


Figure 7. Temporal changes in the cumulative number of sites sampled and species recorded (all reported and excluding suspected morphological variants of other species) in the Arctic from 1895 to 2015. Note the close correspondence in temporal trends. A simple linear correlation of log cumulative number of sites and log cumulative number of species is shown in the inset graph resembling the Preston species-area curve for continguous habit sampling (Preston 1962).

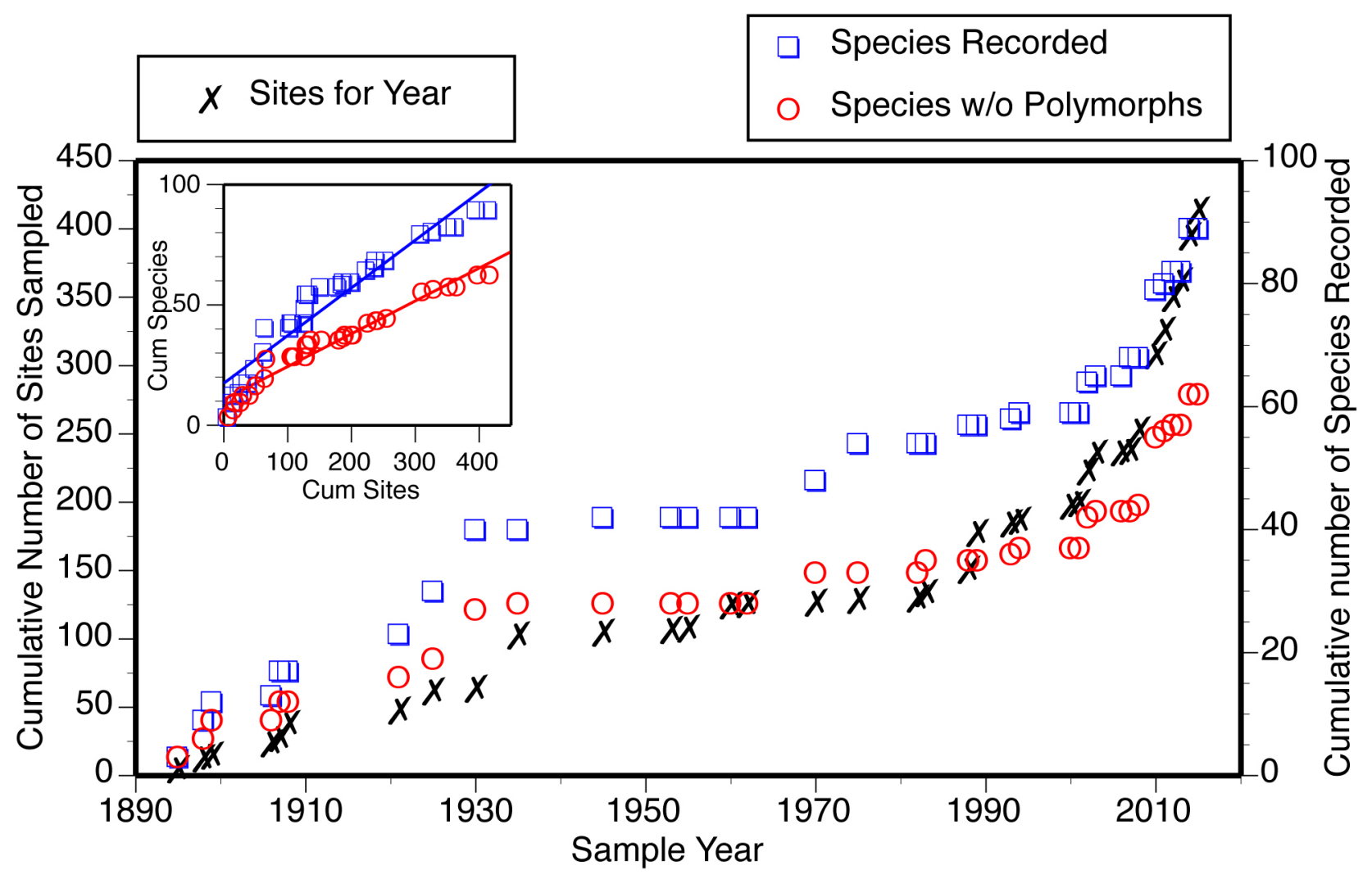


Figure 8. The cumulative number of marine species described from 1875 to 2015 and cumulative number tintinnid species reported from the Arctic from 1885 to 2015 as shown in Fig. 6 . Data on the temporal changes in the species inventory of the Bay of Villefranche (NW Mediterranean Sea) are from Dolan (2016a). Data for total marine species (benthic, nekton, planktonic, parasitic, free-living, etc.) described from WoRMS Editorial Board (2016).

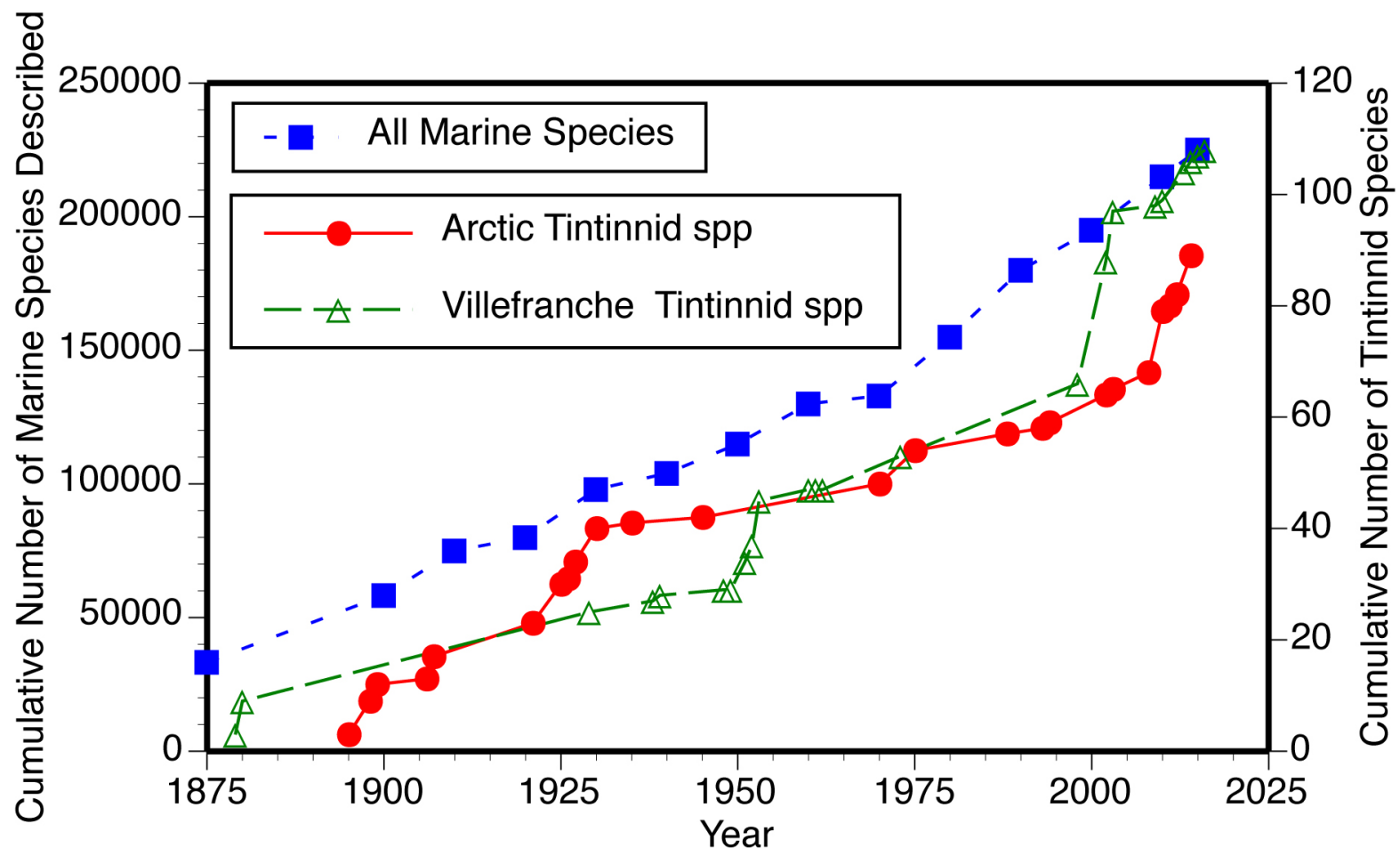


Online Resource Figure 1. Bathymetric Map of Arctic Seas with seas sampled labelled and 'Degrees West' indicated as given in Online Resource Data File.

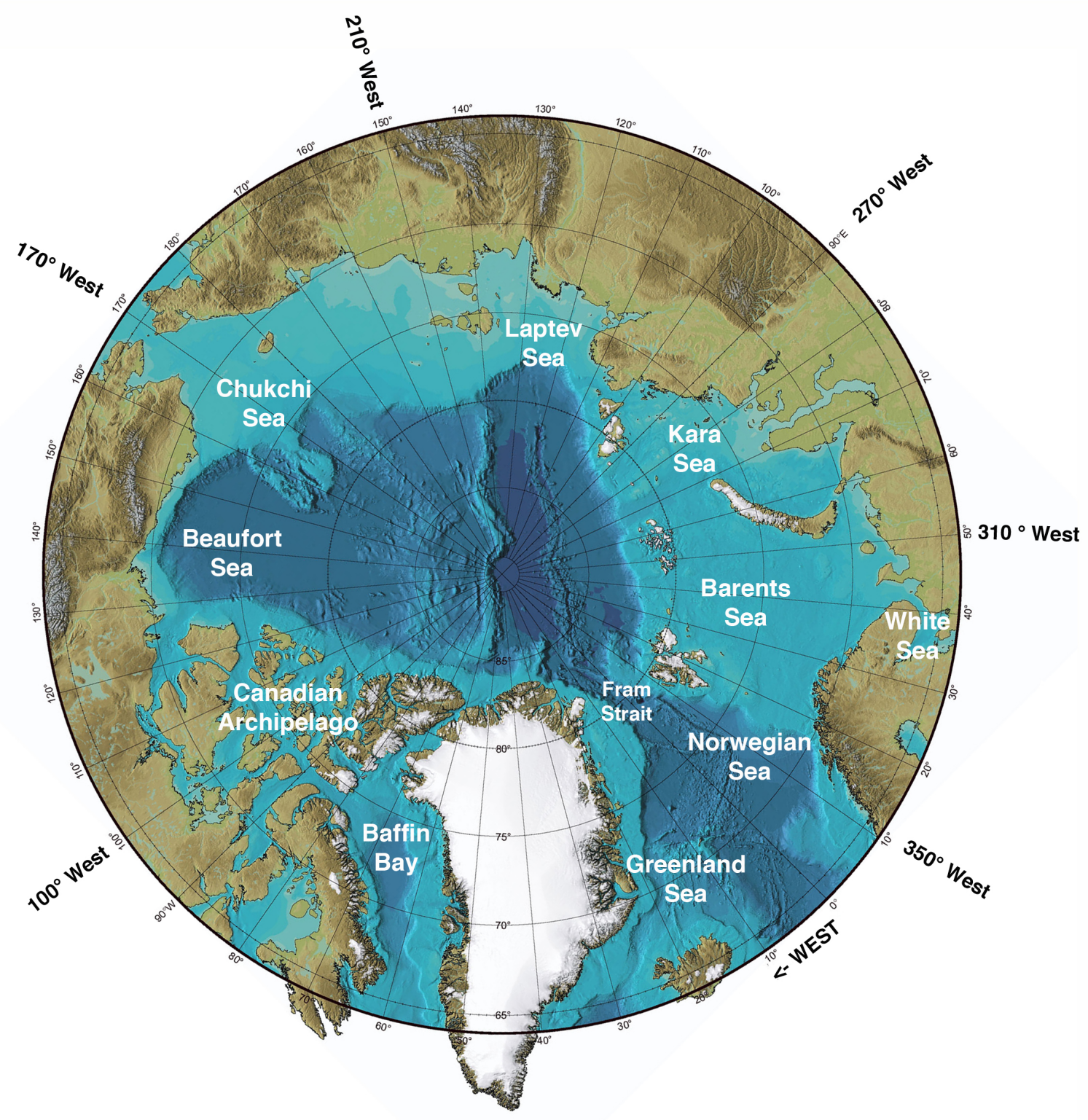

Base map from: Jakobsson, M., L. A. Mayer, B. Coakley, J. A. Dowdeswell, S. Forbes, B. Fridman, H. Hodnesdal, R. Noormets, R. Pedersen, M. Rebesco, H.-W. Schenke, Y. Zarayskaya A, D. Accettella, A. Armstrong, R. M. Anderson, P. Bienhoff, A. Camerlenghi, I. Church, M. Edwards, J. V. Gardner, J. K. Hall, B. Hell, O. B. Hestvik, Y. Kristoffersen, C. Marcussen, R. Mohammad, D. Mosher, S. V. Nghiem, M. T. Pedrosa, P. G. Travaglini, and P. Weatherall. 2012. The International Bathymetric Chart of the Arctic Ocean (IBCAO) Version 3.0, Geophysical Research Letters, doi: 10.1029/2012GL052219. 